\title{
Mass gathering medicine: a practical means of enhancing disaster preparedness in Canada
}

\author{
Adam Lund, BSc, MD, MDE*; Samuel J. Gutman, MD*; Sheila A. Turris, RN, PhD ${ }^{\dagger}$
}

\section{ABSTRACT}

Background: We explore the health care literature and draw on two decades of experience in the provision of medical care at mass gatherings and special events to illustrate the complementary aspects of mass gathering medical support and disaster medicine. Most communities have occasions during which large numbers of people assemble in public or private spaces for the purpose of celebrating or participating in musical, sporting, cultural, religious, political, and other events. Collectively, these events are referred to as mass gatherings. The planning, preparation, and delivery of health-related services at mass gatherings are understood to be within the discipline of emergency medicine. As well, we note that owing to international events in recent years, there has been a heightened awareness of and interest in disaster medicine and the level of community preparedness for disasters. We propose that a synergy exists between mass gathering medicine and disaster medicine.

Method: Literature review and comparative analysis.

Results: Many aspects of the provision of medical support for mass gathering events overlap with the skill set and expertise required to plan and implement a successful medical response to a natural disaster, terrorist incident, or other form of disaster.

Conclusions: There are several practical opportunities to link the two fields in a proactive manner. These opportunities should be pursued as a way to improve the level of disaster preparedness at the municipal, provincial, and national levels.

\section{RÉSUMÉ}

Renseignements contextuels: Nous explorons la littérature en soins de santé et nous nous appuyons sur deux décennies d'expérience dans la prestation de soins médicaux lors des rassemblements de masse et des événements spéciaux pour illustrer les aspects complémentaires du soutien médical apporté durant les rassemblements de masse et la médecine de catastrophe. Dans la plupart des communautés, des activités sont organisées au cours desquelles un grand nombre de personnes se réunissent dans des endroits publics ou privés dans le but de célébrer ou de participer à un événement musical, sportif, culturel, religieux, politique ou autre. Collectivement, on appelle ces événements des rassemblements de masse. La planification, la préparation et la prestation des services liés à la santé lors des rassemblements de masse s'inscrivent dans la discipline de la médecine d'urgence. En outre, nous constatons qu'en raison des événements internationaux des dernières années, il y a eu une plus grande sensibilisation à la médecine de catastrophe, un intérêt accru pour celle-ci et une hausse du niveau de préparation des communautés aux catastrophes. Nous proposons qu'une synergie existe entre la médecine exercée dans le cadre des grands rassemblements de masse et la médecine de catastrophe.

Méthode: Analyse documentaire et analyse comparative

Résultats: De nombreux aspects de la prestation d'un soutien médical lors des rassemblements de masse empiètent sur l'ensemble des compétences et de l'expertise requises pour planifier et mettre en œuvre une intervention médicale réussie permettant de répondre à une catastrophe naturelle, à un attentat terroriste ou à toute autre forme de catastrophe.

Conclusions: II existe plusieurs possibilités concrètes permettant de relier les deux domaines d'une manière proactive. Ces possibilités devraient être considérées comme un moyen d'améliorer le niveau de préparation aux catastrophes, et ce, aux niveaux municipal, provincial et fédéral.

Keywords: crowds, disaster medicine, emergency medical services, mass gathering, prehospital care

The Mass Gathering Medicine (MGM) Interest Group in the Department of Emergency Medicine at the University of British Columbia (UBC) formed in 2008

From the *Department of Emergency Medicine and TSchool of Nursing, University of British Columbia, Vancouver, BC.

Correspondence to: Dr. Adam Lund, 118 Parkside Drive, Port Moody, BC V3H 4W8; adam.lund@ubc.ca

Submitted January 9, 2010; Revised June 2, 2010; Accepted July 21, 2010.

This article has been peer reviewed. 
to formally study the provision of medical care at mass gatherings and special events. Members of this interdisciplinary group, led by emergency physicians, have been participating in and/or coordinating medical responses for mass gatherings over the last two decades. This experience has included management and clinical roles for the 2010 Olympic Winter Games, 2009 World Police and Fire Games, World Cup and world championship sporting events, and numerous races, festivals, and concerts.

Many aspects of the provision of medical support for mass gathering events overlap with the expertise required to plan and implement a successful medical response to a natural disaster, terrorist incident, or mass-casualty event. In this article, we review MGM and disaster medicine (DM) with a focus on the complementary aspects. We propose that because MGM and DM share important traits, the provision of medical care during mass gatherings is an important opportunity for health care providers to gain experience that would be applicable in a DM response. By further developing our body of knowledge and enabling participation in the provision of medical care at mass gatherings, a larger proportion of health care professionals will acquire practical experience that will enhance the level of disaster preparedness in Canada.

\section{MASS GATHERING MEDICINE}

All communities experience occasions during which large numbers of people assemble in public or private spaces for the purpose of celebrating or participating in musical, sporting, cultural, religious, political, or other events. Collectively, these events are referred to as mass gatherings. From the medical perspective, the generally prescribed definition of a mass gathering is an event involving the gathering of individuals or crowds during which an emergency response may be delayed by virtue of limited access or other challenges. ${ }^{1-6}$ This definition encompasses not only a wide range of factors that impact the safety of attendees or participants at events but also the breadth of events and situations where this body of knowledge is relevant and applicable. Other definitions refer only to the size of the gathering, with numbers ranging from crowds of 1,000 to 25,000 . $^{5}$

Large crowds require dedicated first aid, medical, and other health-related services at a rate higher than that of the baseline population. ${ }^{3}$ There is great variability within and between mass gatherings. The weather, event duration, age and behaviour of the crowd, topography, event-specific hazards, use of alcohol or drugs, and whether attendees are participants or simply spectators ${ }^{1,2,7}$ will vary substantially between events. At any single mass gathering, a complex interplay of factors will affect the patient presentation rate (PPR), the acuity, and the case mix.

There is also great heterogeneity across the spectrum of events in terms of the degree of medical support, services, and planning prior to and during an event. ${ }^{3,8-16}$ Services extend from simple first aid provided by single or paired volunteers to full-service field clinics located in tents or trailers staffed by a full array of health care professionals. There is no consensus regarding minimum standards or defining the appropriate levels of service, resources, or personnel required. The configuration, capability, and procedures of the medical team will be impacted by the budget available and the requirements of event promoters and governing agencies. The number, skill level, and event experience of the medical staff will alter the number of patients referred for further care, otherwise known as the medical transfer rate (MTR). The MTR is one measure of the impact of the event on the host community's health care infrastructure.

Staff members at MGM deployments are usually composed of a diverse group of health care providers who come together for the first time in temporary structures in the field and who must function effectively under unfamiliar and challenging circumstances. Staff should be credentialed in advance and protected from liability. They have limited opportunity to prepare and may have only a brief orientation to the event and a cursory knowledge of the medical and operational plans.

MGM at an event often involves periods of extremely high patient volume with variable acuity, usually with limited history available. Mass gatherings often provide environments that complicate the provision of care, including high ambient noise, temperature extremes, precipitation, and uneven topography. Care is provided in temporary structures with limited resources. Health care providers are challenged to function without their familiar clinical systems while attempting to maintain a high standard of care, often for large numbers of patients over a variable and sometimes extended period of time. 
Preparation and advanced planning are crucial to the success of any MGM deployment. For each MGM deployment, issues related to security, communications, restocking, and resupply are essential considerations. Protocol and procedure development, referral planning, and training are aimed at enabling an unfamiliar team to provide appropriate care in a challenging and unpredictable environment. Procedures for documentation must be prepared and used in the field to establish reliable medical records. Documenting follow-up plans and a procedure for maintaining accurate records is required. Planning extends beyond the event site alone to encompass liaison with the supporting emergency medical services systems, as well as local and regional acute care resources. Proximity to hospitals and the capacity of local emergency health services must be considered.

\section{DISASTER MEDICINE}

International events in recent years, including tragic events this year in New Zealand and Japan, have heightened awareness of and interest in DM and the level of preparedness for disasters in communities. ${ }^{2,8,17-20}$ $\mathrm{DM}$ is defined as the practice of medicine in a situation where natural or human-made circumstances lead to community disruption such that the need for health services exceeds the community's ability to provide them. ${ }^{18}$ A DM scenario may occur in the context of a surge in demand beyond the system's capacity to respond or when the health care infrastructure itself is not intact.

In a DM response, care may be provided in damaged, temporary, or field settings by medical team members who may not be familiar with each other. Health care providers must work outside their usual scope of practice without the processes and systems that are embedded in their usual working environments. Frequently, there is an insufficient or inconsistent supply of resources such as water, power, and shelter from the elements, and it is in this context that large numbers of patients must be assessed and triaged rapidly to save lives and limit morbidity.

A frequently repeated tenet is that good disaster response is only possible based on good disaster planning. ${ }^{19-21}$ As such, it is prudent for all levels of government and providers of emergency health services to establish, test, and maintain appropriate disaster plans and equipment stockpiles. A crucial element of good disaster planning is training front-line providers. ${ }^{19,21}$ However, even the most comprehensive plans that include simulation and rehearsal to locate gaps and omissions ${ }^{19}$ lack a practical component or simulation experience that reproduces the chaos and the variable logistical leadership and medical needs of a real event.

Despite the widespread agreement that disaster preparedness is valuable, virtually no studies examine disaster preparedness and its effect on mortality and morbidity.22 DM research is hindered by the unpredictable nature of the events themselves and the relative inability to carry out before-and-after comparisons. ${ }^{22}$ Data collection with regard to disasters lacks a consistent format, ${ }^{23}$ and there is a dearth of sustainable funding in place to support DM research. ${ }^{22,24,25}$ As well, there are few, if any, data and no consensus on the appropriateness, minimum standards, or cost-effectiveness of DM training and preparation..$^{19,26}$ In fact, DM is not yet formally acknowledged as an area of special interest or a medical specialty; there is no established residency training program..$^{27}$ All of these factors combine to contribute to a relative lack of knowledge with regard to the planning, preparation, execution, and evaluation of disaster scenarios.

\section{ENHANCED DISASTER PREPAREDNESS}

There are no formal Canadian education programs to support health care professionals in the development of DM skills. In most communities, there are ad hoc disaster exercises, usually limited to tabletop simulations, which are infrequent, costly, and disruptive. These are often poorly attended by medical staff. $21,26,28$ As a result, most physicians and allied health providers lack experience in disaster planning and, specifically, lack practical experience.

Many of the aspects of a DM response and MGM deployment are analogous (Table 1). Given the commonalities between DM and MGM, training and participation in mass gathering events provide a controlled and readily available proxy to enable large numbers of health care providers across Canada to gain experience and training applicable to DM over time. Participation in MGM will provide the required maintenance and enhancement of existing skills applicable to DM. ${ }^{25}$ Participation in MGM will augment the level of preparedness provided by traditional tabletop or walk-through DM exercises. Dissemination of practical 
Table 1. Mass gathering medicine and disaster medicine comparison

\begin{tabular}{|c|c|c|c|}
\hline Themes & $\begin{array}{c}\text { Specific } \\
\text { considerations }\end{array}$ & Similarities & Differences \\
\hline \multirow[t]{6}{*}{ Logistics planning } & Location & $\begin{array}{l}\text { Temporary: fields, stadiums, tents, roadside, } \\
\text { other temporary structures }\end{array}$ & In DM, may be damaged infrastructure \\
\hline & Environment & $\begin{array}{l}\text { Variable temperature, wind, humidity, } \\
\text { precipitation. Power and lighting are often } \\
\text { limited. Clean water needs. Sanitation } \\
\text { temporary. }\end{array}$ & $\begin{array}{l}\text { Unsafe in DM with additional structural and } \\
\text { environmental hazards. DM response may } \\
\text { occur in hospitals with much increased } \\
\text { patient volume. }\end{array}$ \\
\hline & Equipment & $\begin{array}{l}\text { Limited supplies and medical equipment. } \\
\text { Care provided on blankets, camping cots, } \\
\text { tables, etc. }\end{array}$ & $\begin{array}{l}\text { Diagnostic and definitive treatment } \\
\text { responsibility in DM may be field based. } \\
\text { MGM event teams refer advanced cases to } \\
\text { definitive care. }\end{array}$ \\
\hline & Communications & $\begin{array}{l}\text { Always a challenge. Two-way radios, cellular } \\
\text { phones, and text messaging. }\end{array}$ & $\begin{array}{l}\text { Telephone lines may not be reliable in DM. } \\
\text { Increased planning with MGM. }\end{array}$ \\
\hline & Multiagency response & $\begin{array}{l}\text { Coordination with other agencies essential: } \\
\text { security, operations, logistics, EMS, and } \\
\text { hospitals }\end{array}$ & $\begin{array}{l}\text { In DM, professional responders provide } \\
\text { leadership on site. May include military } \\
\text { support. }\end{array}$ \\
\hline & Budget & $\begin{array}{l}\text { Often limited, restricting the quantity and } \\
\text { breadth of equipment available }\end{array}$ & $\begin{array}{l}\text { MGM may permit more planning based on } \\
\text { knowledge of past events. Less opportunity } \\
\text { for resource planning in DM. }\end{array}$ \\
\hline \multirow[t]{3}{*}{ Personnel and team } & Responders & $\begin{array}{l}\text { Mixed, interdisciplinary teams from a variety } \\
\text { of practice settings and institutions } \\
\text { working in an unfamiliar environment. } \\
\text { Volunteerism is common in early response. }\end{array}$ & $\begin{array}{l}\text { In MGM, personnel choose to attend and } \\
\text { participate. In DM, some team members } \\
\text { participate owing to proximity and necessity, } \\
\text { not choice. }\end{array}$ \\
\hline & Reimbursement & $\begin{array}{l}\text { Mix of paid, honorarium, and volunteer. } \\
\text { Volunteers commonly staff nonprofit and } \\
\text { high-interest events. }\end{array}$ & $\begin{array}{l}\text { Variable. Professional responders reimbursed } \\
\text { through special funding when required. }\end{array}$ \\
\hline & Case mix & $\begin{array}{l}\text { Triage is essential. Acuity of patient } \\
\text { presentations can vary from trivial to life- } \\
\text { threatening. }\end{array}$ & $\begin{array}{l}\text { MGM has reasonable upper limit to scope of } \\
\text { care; DM response requires full-scope, } \\
\text { ongoing critical care }\end{array}$ \\
\hline \multirow[t]{2}{*}{$\begin{array}{l}\text { Predictability of } \\
\text { needs }\end{array}$} & Planning & $\begin{array}{l}\text { MGM experience, literature, and available } \\
\text { budget guides planning. Past disaster } \\
\text { experience, literature, and budgets guide } \\
\text { DM preparation. DM planning possible with } \\
\text { respect to risk assessment in a } \\
\text { community. }\end{array}$ & $\begin{array}{l}\text { DM usually an unplanned event; needs for } \\
\text { services not fully predictable. Mass } \\
\text { casualties at MGM can occur also. }\end{array}$ \\
\hline & Timing & $\begin{array}{l}\text { MGM often a time limited event (from a few } \\
\text { hours, to several days). True also of many } \\
\text { disasters (i.e., public transport collisions, } \\
\text { explosions, etc.) }\end{array}$ & $\begin{array}{l}\text { In DM, timing of event is variable (from hours, } \\
\text { days, weeks, etc.). Services required on a } \\
24 / 7 \text { basis. }\end{array}$ \\
\hline
\end{tabular}

knowledge in MGM as a proxy for DM could help address the international call for improved disaster preparedness in communities (see Table 1)..$^{21,22,24,25,28}$

The science of MGM is at an early stage of development. The existing literature is primarily descriptive. Access to reliable data regarding previous MGM experience at similar events held in other locations ${ }^{26}$ is crucial to appropriate planning but often not available. Host cities must have access to information about the hazards of previous, similar events held in other locations, such as the probability of substance abuse by expected crowds, fencing in of the event, weather effects, pyrotechnics, sport-related risks, and specific population risks. ${ }^{29}$ For example, in 2009,
Vancouver hosted the World Police and Fire Games, a biennial sporting event including more than 10,000 athletes. Information about injury rates, patient presentation rates, and so on would have been valuable during the planning process but was not available. A pioneering research group in Australia has endeavoured to apply increased rigour to MGM research. ${ }^{1,4,5}$ At UBC, we have developed and commenced populating a mass gathering patient registry (at www.ubcmgm. $\mathrm{ca} /$ registry) to generate an evidentiary foundation for the practice of MGM. This registry houses data that will enable us to support projections of PPR, MTR, and the resources required for a variety of events and mass gatherings. 
The next steps to building improved disaster preparedness through MGM exposure require a focus on clinical practice, communication, education, policy, and research:

1. To support clinical practice, the UBC MGM Interest Group is developing infrastructure to support the planning and execution of local MGM events. This infrastructure includes guidelines for staffing, processes, and the development of systematic approaches to logistical issues such as supplies, personnel mix, and medical support layout.

2. The UBC MGM Interest Group will provide a central resource for departments of emergency medicine across the country, drawing together researchers and clinicians with similar interests. At a local level, we have a platform to communicate with providers about MGM events occurring in the province.

3. We have developed and offered an MGM elective for residents and medical students at UBC since 2008. To expand this to other care providers provincially and nationally, we intend to use a distance education format that teaches the theoretical foundations of both MGM and DM that can be accessed by learners in any location across the country. There must be an accompanying clinical component practiced at MGM events, with the best practices derived from research used and reinforced.

4. Policy makers will be recruited to support MGM as a vehicle to enhance disaster preparedness at the local, provincial, and national levels. Sustainable funding will be a key issue in these discussions, as has been identified in the health care literature. ${ }^{22}$

5. As discussed, MGM research is in its infancy. Numerous questions require clarification, including

- Best methodologies for standardized data collection

- The development of a triage system that can be used in the field by members of the medical support team with minimal orientation or training

- The impact of MGM education on both perceptions of individual/team preparedness and actual preparedness

- Cost-effectiveness of MGM as a means of enhancing disaster preparedness

- Minimum standards for equipment, staffing and skill mix, and command and control structures for MGM

\section{SUMMARY AND CONCLUSIONS}

MGM and DM share important traits that can be used to enhance disaster preparedness. The provision of medical care during mass gatherings is an important opportunity for health care providers to gain experience that would be applicable and desirable in a DM response. Formalized training and practical field experience in MGM will result in greater numbers of health care providers with skills and expertise that are desirable in a disaster. MGM involvement offers a practical and cost-effective strategy for governments to enhance disaster preparedness and improves the level of care available at large community events. Expanded understanding, research, and deployment of MGM are still required; however, implementation of an easy-toaccess and available network of MGM event opportunities and providers and procedures to enable participation and education for clinicians could help improve disaster preparedness across Canada.

Acknowledgement: The authors gratefully recognize Jessica M. Miller, who provided invaluable editorial review of the manuscript.

Competing interests: Dr. Gutman is president of Rockdoc Consulting Inc., a commercial provider of medical support for mass gatherings and large-scale special events.

\section{REFERENCES}

1. Arbon P. Mass-gathering medicine: a review of the evidence and future directions for research. Prehosp Disaster Med 2007; 22:131-5.

2. Milsten AM, Maguire BJ, Billell RA, et al. Mass-gathering medical care: a review of the literature. Prehosp Disaster Med 2002;17:151-62.

3. Hodgetts TJ, Cooke MW. The largest mass gathering. BM7 1999;318:957-8.

4. Arbon P, Bridgewater FHG, Smith C. Mass gathering medicine: a predictive model for patient presentation and transport rates. Prehosp Disaster Med 2001;16:109-16.

5. Arbon P. The development of conceptual models for massgathering health. Prehosp Disaster Med 2004;19:208-12 .

6. Tintinalli JE, Kelen GD, Stapczynski JS. Emergency medicine: a comprehensive study guide. McGraw-Hill Professional; 2004.

7. Enock KE, Jocobs J. The Olympic and Paralympic Games 2012: literature review of the logistical planning and operational challenges for public health. Public Health 2008;122:1299-38, doi:10.1016/j.puhe.2008.04.016.

8. Delaney JS, Drummond R. Mass casualties and triage at a sporting event. Br 7 Sports Med 2002;36:85-8, doi:10.1136/ bjsm.36.2.85. 
9. Hewitt S, Jarrett L, Winter B. Emergency medicine at a large rock festival. 7 Accid Emerg Med 1996;13:26-7.

10. Perdomo RVP, Rivera CAM, Becerra AMM, et al. Public health surveillance during the XVII Central American and Caribbean Games-Puerto Rico, November 1993. MMWR Morb Mortal Wkly Rep 1996;45:581-4.

11. Sloan B, Somerville G, Olinger M, et al. Injury incidence during the 2001 World Police and Fire Games. Am 7 Emerg Med 2004;22:129-30.

12. Thierbach AR, Wolcke BB, Peipho T, et al. Medical support for children's mass gatherings. Prehosp Disaster Med 2003;18: 14-9.

13. Zeitz K, Zeitz C, Kadow-Griffen C. Injury occurrences at a mass gathering event. 7 Emerg Primary Health Care 2005;3:1-10.

14. Zeitz KM, Schneider DPA, Jarrett D, et al. Mass gathering events: retrospective analysis of patient presentations over seven years at an agricultural and horticultural show. Prehosp Disaster Med 2002;17:147-50.

15. Olapade-Olaopa EO, Alonge TO, Amanor-Boadu SD, et al. On-site physicians at a major sporting event in Nigeria. Prehosp Disaster Med 2005;21:40-4.

16. Mormura N, Katsumi A, Koido Y, et al. Analysis of patient load data from the FIFA World Cup Korea/Japan. Prehosp Disaster Med 2004;19:279-84.

17. Arquilla B, Paladino L, Reich C, et al. Using a joint triage model for multi-hospital response to a mass casualty incident in New York City. 7 Emergencies Trauma Shock 2009;2:114-6, doi:10.4103/0974-2700.50746.

18. Teich JM, Wagner MM, MacKenzie CF, et al. The informatics response in disaster, terrorism, and war. FAMIA 2002;9:97-104, doi:10.1197/jamia.M1055.

19. Hsu EB, Thomas TL, Bass EB, et al. Healthcare worker competencies for disaster training. BMC Med Educ 2006; 6(19):1-9.
20. Hochstein C, Arnesen S, Goshorn J, et al. Selected resources for emergency and disaster preparedness and response from the United States National Library of Medicine. Med Ref Serv Q 2008;27(1):1-20.

21. Khorram-Manesh A, Hedelin A, Ortenwall P. Regional coordination in medical emergencies and major incidents; plan, execute and teach. Scand 7 Trauma Resuscitation Emerg Med 2009;17(32):1-6.

22. Auf der Heide E. The importance of evidence-based disaster planning. Ann Emerg Med 2006;47:34-49, doi:10.1016/ j.annemergmed.2005.05.009.

23. Birnbaum ML. Disaster medicine: status, roles, responsibilities, and needs. Prehosp Disaster Med 2002;17:117-8.

24. Cherry RA, Trainer $M$. The current crisis in emergency care and the impact on disaster preparedness. BMC Emerg Med 2008;8(7):1-7.

25. Ziskin LZ, Harris DA. State health policy for terrorism preparedness. Am 7 Public Health 2007;97:1583-8, doi:10.2105/ AJPH.2006.101436.

26. Pfenninger EG, Domres BD, Stahl W, et al. Medical student disaster medicine education: the development of an educational resource. Int 7 Emerg Med 2010;3:9-20, doi:10.1007/s12245009-0140-9.

27. Koenig KL, Bey T, Schultz CH. International disaster medical sciences fellowship: model curriculum and key consideration for establishment of an innovative international educational program. West 7 Emerg Med 2009;10: 213-9.

28. Kollek D. Canada's ability to respond to a national health crisis hampered by jurisdictional issues, untested emergency plans. CMA7 2009;180:1193-4.

29. Khan K, Freifeld CC, Wang J, et al. Preparing for infectious disease threats at mass gatherings: the case of the Vancouver 2010 Olympic Winter Games. CMAJ 2010;182:579-83. 